Article

\title{
Design, Overproduction and Purification of the Chimeric Phage Lysin MLTphg Fighting against Staphylococcus aureus
}

\author{
Feng Wang ${ }^{1,+}{ }^{\circ}$, Xiaohang Liu ${ }^{1,+}$, Zhengyu Deng ${ }^{1,+}$, Yao Zhang ${ }^{1,+}$, Xinyu Ji ${ }^{1}$, Yan Xiong ${ }^{1}$ \\ and Lianbing Lin 1,2 ,* \\ 1 Faculty of Life Science and Technology, Kunming University of Science and Technology, \\ 727 South Jingming Road, Kunming 650500, China; wangfeng076@hotmail.com (F.W.); \\ 1xh667295@hotmail.com (X.L.); dzy19950329@hotmail.com (Z.D.); zyao@stu.kust.edu.cn (Y.Z.); \\ jixinyu@stu.kust.edu.cn (X.J.); xiongyan@stu.kust.edu.cn (Y.X.) \\ 2 Engineering Research Center for Replacement Technology of Feed Antibiotics of Yunnan College, \\ 727 South Jingming Road, Kunming 650500, China \\ * Correspondence: linlb@kust.edu.cn; Tel.: +86-139-8768-1986; Fax: +86-0871-65920570 \\ + These authors contributed equally to this work.
}

Received: 13 October 2020; Accepted: 24 November 2020; Published: 1 December 2020

\begin{abstract}
With the increasing spread of multidrug-resistant bacterial pathogens, it is of great importance to develop alternatives to conventional antibiotics. Here, we report the generation of a chimeric phage lysin, MLTphg, which was assembled by joining the lysins derived from Meiothermus bacteriophage MMP7 and Thermus bacteriophage TSP4 with a flexible linker via chimeolysin engineering. As a potential antimicrobial agent, MLTphg can be obtained by overproduction in Escherichia coli BL21(DE3) cells and the following Ni-affinity chromatography. Finally, we recovered about $40 \pm 1.9 \mathrm{mg}$ of MLTphg from $1 \mathrm{~L}$ of the host E. coli BL21(DE3) culture. The purified MLTphg showed peak activity against Staphylococcus aureus ATCC6538 between 35 and $40{ }^{\circ} \mathrm{C}$, and maintained approximately $44.5 \pm 2.1 \%$ activity at room temperature $\left(25^{\circ} \mathrm{C}\right)$. Moreover, as a produced chimera, it exhibited considerably improved bactericidal activity against Staphylococcus aureus $\left(2.9 \pm 0.1 \log _{10}\right.$ reduction was observed upon $40 \mathrm{nM}$ MLTphg treatment at $37^{\circ} \mathrm{C}$ for $30 \mathrm{~min}$ ) and also a group of antibiotic-resistant bacteria compared to its parental lysins, TSPphg and MMPphg. In the current age of growing antibiotic resistance, our results provide an engineering basis for developing phage lysins as novel antimicrobial agents and shed light on bacteriophage-based strategies to tackle bacterial infections.
\end{abstract}

Keywords: bacteriophage; endolysin; bioengineering; pathogen control; Staphylococcus aureus; antibiotic-resistant bacteria; antimicrobial drug; biotechnology

\section{Introduction}

As a potential antibacterial agent permeating the entire biosphere and existing in substantial numbers, bacterial viruses, or bacteriophages, were estimated to be $10^{31}$ particles on the planet, ten times greater than their bacterial counterparts [1]. Given the threat of alarming antibiotic resistance, bacteriophage-based strategies have recently gained renewed interest because of their advantages including safety, high specificity, relative abundance and low possibility of developing resistance over conventional antibiotics in the control of bacterial infections [2]. Besides the whole particles, a phage technology revolution also includes phage lytic enzymes (phage lysins), which are usually bacterial cell wall hydrolytic enzymes encoded by the double-stranded DNA phages to rupture susceptible bacteria and release progeny virions. They are able to cleave to the peptidoglycan bonds of Gram-positive 
or Gram-negative bacteria, digesting their cell walls and resulting in bacterial lysis, and thus have potential applications in the areas of microbial industry, clinical practice and biotechnology.

Recently, lines of reports have highlighted that the upgraded features and improved properties of phage lysins can be achieved by protein modification and engineering of new derivatives [3], and there are many different modification or engineering strategies, including site-directed mutagenesis, swapping or exchange of functional domains, and a combination of full-length lytic enzymes [4-6], which have been utilized to improve specific enzybiotic features of phage lysins. Among these engineering approaches, fusion of phage lytic enzymes of heterologous origins have also been investigated and the numerous examples of chimeolysins with enhanced characteristics were produced. Significantly, they showed great improvements in comparison to their parental lysins or to other lytic enzymes [7-9].

For the generation of multi-functional chimera harboring domains from various origins, different types of domain linkers can be included between individual moieties to avoid undesirable inter-domain interaction or folding interference [10]. Among them, the flexible peptides (GGGGS) $n(1 \leq \mathrm{n} \leq 6)$ or $\alpha$-helical spacers (EAAAK)n ( $\mathrm{n}$ usually $\leq 3$ ) are often used in order to control the distance of two modules for favorable interaction and to enhance the efficiency of fusion proteins [11]. Moreover, Trinh et al. have also reported that a remarkable enhancement of the recombinant fusion protein expression can be achieved by manipulating the (GGGGS)3 linker sequence [12].

Previously, we have identified two lysins, namely, MMPphg and TSPphg, by sequencing and annotating the genome of Meiothermus bacteriophage MMP7 [13] and Thermus bacteriophage TSP4 [14], respectively. Both lysins have exhibited bactericidal activity against a panel of multidrug-resistant bacterial pathogens, but they are most active between 50 and $65^{\circ} \mathrm{C}$, making the effectiveness and practicability of these two lysins decreased at lower temperatures. In this study, by combining full-length MMPphg and TSPph lysins of heterologous origins via bioengineering, we have improved the potential of the produced chimeolysin, MLTphg, as a promising antimicrobial agent against a panel of pathogenic bacteria.

\section{Materials and Methods}

\subsection{Bacterial Strains}

Escherichia coli strain BL21(DE3) (Tsingke Biotechnology, Beijing, China) was used as the host for recombinant protein overproduction and it was cultured in LB medium $(10 \mathrm{~g} / \mathrm{L}$ tryptone, $10 \mathrm{~g} / \mathrm{L}$ yeast extract, $5 \mathrm{~g} / \mathrm{L} \mathrm{NaCl}, \mathrm{pH}=7.2 \pm 0.2)$ at $37^{\circ} \mathrm{C}$ with 150 -rpm shaking. The Staphylococcus aureus strain ATCC 6538 was cultivated at $37^{\circ} \mathrm{C}$ in Nutrient Agar medium $(10 \mathrm{~g} / \mathrm{L}$ tryptone, $3 \mathrm{~g} / \mathrm{L}$ beef extract, $5 \mathrm{~g} / \mathrm{L} \mathrm{NaCl}, \mathrm{pH}=7.2 \pm 0.2$ ) with shaking at $150 \mathrm{rpm}$. The clinical isolates of Klebsiella pneumoniae were grown at $37^{\circ} \mathrm{C}$ in a Brain Heart Infusion medium $(10 \mathrm{~g} / \mathrm{L}$ tryptone, $12.5 \mathrm{~g} / \mathrm{L}$ brain infusion powder, $5 \mathrm{~g} / \mathrm{L}$ beef heart powder, $5 \mathrm{~g} / \mathrm{L} \mathrm{NaCl}, 2 \mathrm{~g} / \mathrm{L}$ glucose, $2.5 \mathrm{~g} / \mathrm{L} \mathrm{Na}_{2} \mathrm{HPO}_{4}, \mathrm{pH}=7.4 \pm 0.2$ ) with shaking at $150 \mathrm{rpm}$. The Lactobacillus plantarum strain CGMCC1.16089 was cultured in MRS medium containing $10 \mathrm{~g} / \mathrm{L}$ peptone, $10 \mathrm{~g} / \mathrm{L}$ meat extract, $5 \mathrm{~g} / \mathrm{L}$ yeast extract, $5 \mathrm{~g} / \mathrm{L}$ glucose, $5 \mathrm{~g} / \mathrm{L}$ sodium acetate, $2 \mathrm{~g} / \mathrm{L}$ citric acid diamine, $1 \mathrm{~g} / \mathrm{L}$ tween $80,2 \mathrm{~g} / \mathrm{L}$ dipotassium hydrogen phosphate, $0.2 \mathrm{~g} / \mathrm{L}$ magnesium sulfate- $7 \mathrm{H}_{2} \mathrm{O}$, $0.05 \mathrm{~g} / \mathrm{L}$ manganese sulfate- $\mathrm{H}_{2} \mathrm{O}, 13 \mathrm{~g} / \mathrm{L}$ agar, with a final $\mathrm{pH}$ of 6.8 . The host bacterium for phage TSP4, Thermus sp. TC4 isolated by our laboratory, was cultured at $60^{\circ} \mathrm{C}$ in DSM88 medium with shaking as previously described [15], while the host bacterium for phage MMP7, Meiothermus sp. TC7 was grown at $55^{\circ} \mathrm{C}$ according to methods published elsewhere [16]. All the other strains used in this study were cultivated in LB medium at $37^{\circ} \mathrm{C}$ with 150-rpm shaking. The bacterial strains used as substrates for MLTphg lysin were commercially ordered from the American Type Culture Collection (Manassas, VA) (Staphylococcus aureus ATCC6538), China General Microbiological Culture Collection Center (Beijing) (Salmonella ser. Typhi CGMCC1.1190 and Lactobacillus plantarum CGMCC1.16089) or National Center for Medical Culture Collections (Beijing, China) (Salmonella ser. Paratyphi B CMCC(B)50094 and Salmonella ser. Enteritidis CMCC(B)50335). The clinical isolates of Klebsiella in 
Table 1 were kindly provided by Prof. Xueshan Xia in the Research Center of Molecular Medicine of Yunnan Province, with their drug resistance profiles established following susceptibility tests of the CLSI (Clinical and Laboratory Standards Institute) instructions [17,18]. All the other bacterial strains were stored in our laboratory. When necessary, the bacterial media were fortified with $100 \mu \mathrm{g} / \mathrm{mL}$ ampicillin (Yuanye, Shanghai, China) or $50 \mu \mathrm{g} / \mathrm{mL}$ kanamycin (BioFroxx, Einhausen, Germany). For reagents used for bacterial media, citric acid diamine and glucose were purchased from DaMao chemical reagents (Tianjing, China); $\mathrm{Na}_{2} \mathrm{HPO}_{4}$, dipotassium hydrogen phosphate, magnesium sulfate- $7 \mathrm{H}_{2} \mathrm{O}$, and manganese sulfate- $\mathrm{H}_{2} \mathrm{O}$ were purchased from Fengchuan chemical reagents (Tianjing, China); sodium acetate was ordered from XiLong Scientific (Shantou, China); $\mathrm{NaCl}$ was ordered from BioFount (Beijing, China); tryptone and yeast extract were obtained from Angel Yeast (Yichang, China); agar was purchased from Solarbio Science\&Technology (Beijing, China).

Table 1. Comparison of the bactericidal activity between MLTphg and its parental lysins against various Gram-negative or Gram-positive bacterial strains.

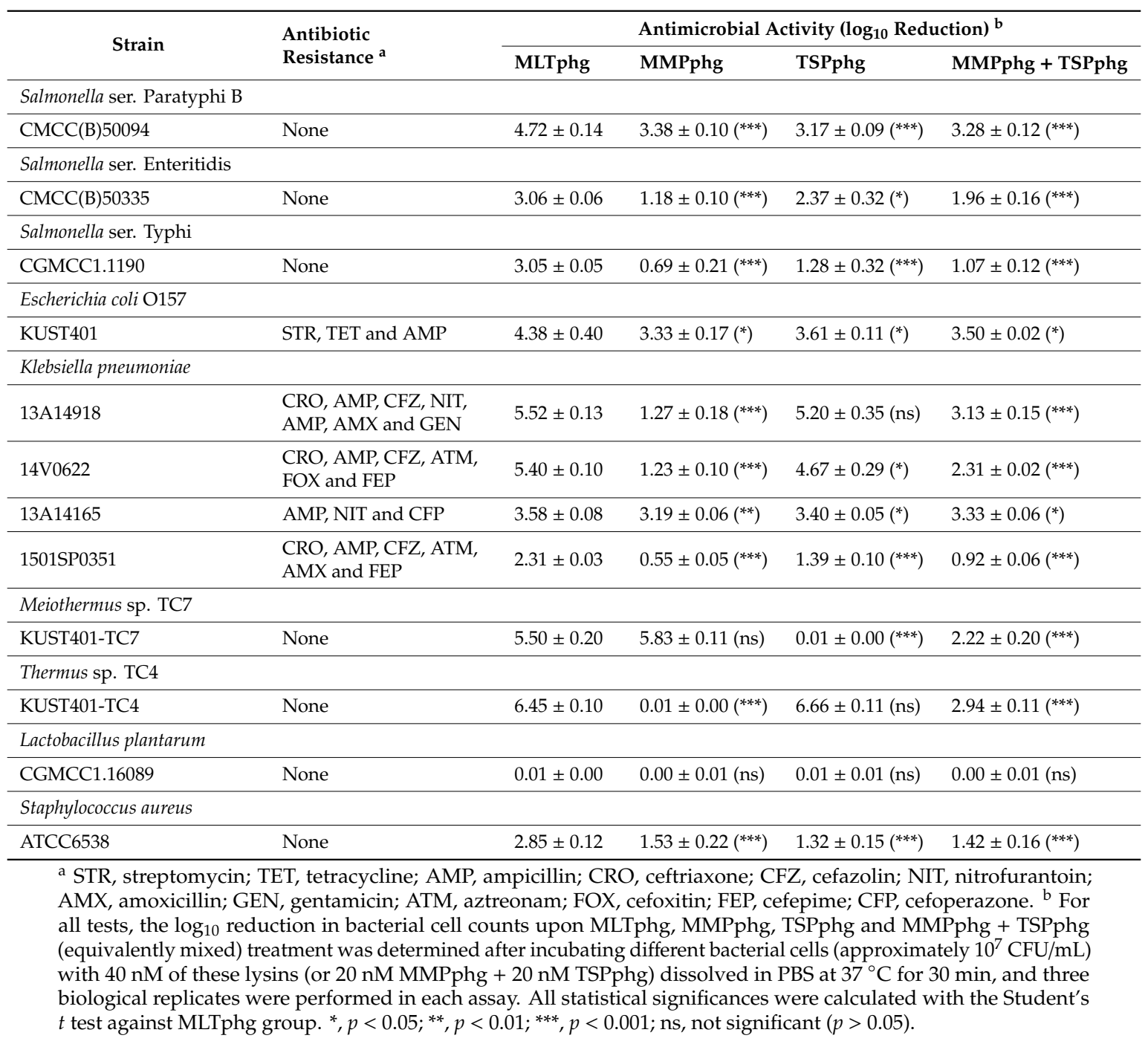

\subsection{Plasmid Construction}

Schematic presentation of cloning strategy for the chimeric MLTphg construct is provided in Figure 1. Firstly, the genes of parental lysins, MMPphg and TSPphg derived from Meiothermus bacteriophage MMP7 and Thermus bacteriophage TSP4, respectively, were amplified by a standard PCR on purified genomic DNA of the respective phages. The specific primers for MMPphg 
gene were as follows: forward: 5'-CCCATGGCAATGCGCATCGTTCATCCCTT-3' and reverse: 5'-GGTGGTGGTGGTTCAGGAGGAGGAGGAACTTTGCAATGCGCGATTTG-3'. The 5' ends of forward and reverse primers carried NcoI restriction site and the designed linker sequence (1-30 bp) (both were underlined), respectively. The specific primers for TSPphg gene were as follows: forward: 5'-CCACCACCACCAAGTCCACCTCCACCTAGTATGCGTCTACCGACTAAGAC-3' and reverse: 5'-ATAGCGGCCGCACCGACTTGGCCCCAGTC-3'. The 5' ends of forward and reverse primers carried the designed linker sequence (15-45 bp) and NotI restriction site (both were underlined), respectively. Finally, the MLTphg lysin gene was amplified by PCR with the following primers: (forward: 5'-CCCATGGCAATGCGCATCGTTCATCCCTT-3' and reverse: 5'-ATAGCGGCCGCACCGACTTGGCCCCAGTC-3'). The $5^{\prime}$ ends of forward and reverse primers contained the NcoI and NotI restriction sites (underlined), respectively. The amplified MLTphg DNA fragment was then used for directional cloning into the vector pET28a. Furthermore, the constructed vector (pET28a-MLTphg) carrying the gene coding for MLTphg lysin was transformed into the host E. coli BL21(DE3) strain and was confirmed by double restriction enzyme cutting analysis and automated DNA sequencing. All PCR procedures were carried out as follows: starting denaturation at $94{ }^{\circ} \mathrm{C}$ for $3 \mathrm{~min}$, followed by 30 cycles of $94^{\circ} \mathrm{C}$ for $45 \mathrm{~s}, 58^{\circ} \mathrm{C}$ for $30 \mathrm{~s}$, and $72{ }^{\circ} \mathrm{C}$ for $90 \mathrm{~s}$.

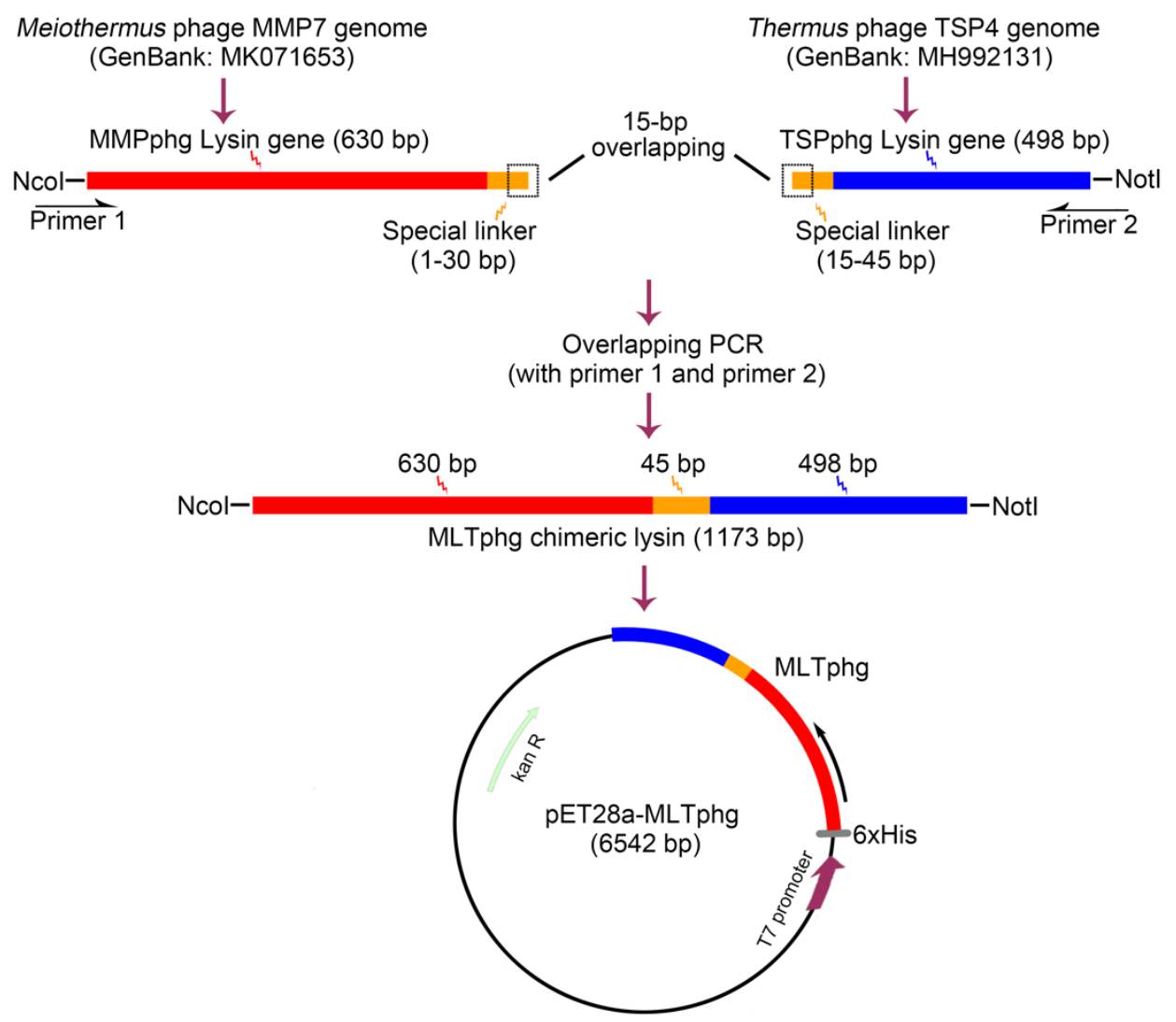

Figure 1. Schematic illustration of the strategy for constructing the recombinant expression vector of chimeric lysin MLTphg (pET28a-MLTphg) via chimeolysin bioengineering.

\subsection{Recombinant Protein Expression and Purification}

E. coli BL21(DE3) cells containing the recombinant pET28a-MLTphg plasmid that enabled overproduction of MLTphg harboring an N-terminal His-tag sequence was utilized as the host for recombinant protein production, and the bacterial cells were cultivated at $37^{\circ} \mathrm{C}$ in $\mathrm{LB}$ medium with shaking at $150 \mathrm{rpm}$. When $\mathrm{OD}_{600}$ reached 1.2, lactose was added with a final concentration of $1 \mathrm{~g} / \mathrm{L}$ to induce recombinant protein overproduction, and the cells were maintained at $37^{\circ} \mathrm{C}$ for another $6 \mathrm{~h}$ of growth. After induction, cells were centrifugated at $1000 \times g$ for $10 \mathrm{~min}$ at $4{ }^{\circ} \mathrm{C}$, and when necessary, 
the pellets can be stored in a freezer at $-80^{\circ} \mathrm{C}$ until further use. The ultrasonication was carried out as described previously [19] with a Sonics VCX500 (Sonics \& Materials Inc., Newtown, CT, USA) and the acoustic power was set as $120 \mathrm{~W}$ ( $0.5 \mathrm{~s}$ on and $0.5 \mathrm{off})$. After sonication, the cell debris was pelleted by centrifuging at $12,000 \times g$ for $10 \mathrm{~min}$ at $4{ }^{\circ} \mathrm{C}$. For Ni-affinity purification of the recombinant protein, a HisTrap ${ }^{\mathrm{TM}} \mathrm{HP}$ column was employed following the manufacturer's guidelines (GE Healthcare, Pittsburgh, PA, USA), and the target protein was obtained by eluting with imidazole (from 50 to $500 \mathrm{mM}$ ). Then, the pooled proteins were dialyzed against $20 \mathrm{mM}$ Tris- $\mathrm{HCl}$ ( $\mathrm{pH}$ 7.4) overnight. The final purified MLTphg was further analyzed by $12 \%$ SDS-PAGE.

\subsection{Determination of Protein Concentrations}

The protein concentrations were determined quantitatively using the routine Bradford measurement, as described previously [19]. Bovine serum albumin (BSA) in a graded concentration series were used as the known standards, and the final $\mathrm{OD}_{595}$ was measured with a spectrophotometer (V729, YOKE, Shanghai, China).

\subsection{Assessing Effects of Temperature, $\mathrm{pH}, \mathrm{NaCl}$ and Metal Ions on the Activity of MLTphg}

To evaluate the optimum working conditions and bacteriolytic activity of the chimeric lysin MLTphg, the Staphylococcus aureus strain ATCC6538 was used as the substrate, cultured to mid-exponential phase $\left(\mathrm{OD}_{600}=0.6-0.8\right)$ and treated with MLTphg at $40 \mathrm{nM}$ prepared in PBS containing $137 \mathrm{mM} \mathrm{NaCl}$, $2.7 \mathrm{mM} \mathrm{KCl}, 4.3 \mathrm{mM} \mathrm{Na}_{2} \mathrm{HPO}_{4}$ and $1.4 \mathrm{mM} \mathrm{KH}_{2} \mathrm{PO}_{4}$ for $30 \mathrm{~min}$ with continuous stirring over a temperature range of $15-50{ }^{\circ} \mathrm{C}$, and then the absorbance was assessed at $600 \mathrm{~nm}$, as previously described [20]. Similarly, the lytic activity of MLTphg was also monitored over a range of $\mathrm{pH}$ values (4 to 9) or $\mathrm{NaCl}$ concentrations (from 0 to $700 \mathrm{mM}$ ). Lysis of the bacterial cells by MLTphg was also measured without or with the addition of metal ions $\left(\mathrm{Mg}^{2+}, \mathrm{Zn}^{2+}, \mathrm{Mn}^{2+}, \mathrm{Ca}^{2+}, \mathrm{Fe}^{2+}\right.$, $\mathrm{Na}^{+}$and $\mathrm{K}^{+}$) at a final concentration of $1 \mathrm{mM}$. For all experiments, assays were repeated in triplicate, and the relative activity of MLTphg was determined as follows: $\left[\mathrm{OD}_{600}\right.$ (buffer only)- $\mathrm{OD}_{600}$ sample (lysin added)]/initial $\mathrm{OD}_{600}$, as previously described [21,22].

\subsection{Antibacterial Assays}

To examine the bactericidal activity of purified MLTphg and compare it to its parental lysins TSPphg and MMPphg, the Staphylococcus aureus ATCC6538 and also a panel of Gram-negative or Gram-positive bacteria were used as the lysin substrates and tested following previously described methods published elsewhere [14,23]. In brief, the bacterial cells were cultured at $37^{\circ} \mathrm{C}$ in a rotary shaker at $150 \mathrm{rpm}$ to mid-exponential phase $\left(\mathrm{OD}_{600}=0.6-0.8\right)$. Subsequently, the cells were collected and prepared in PBS containing $137 \mathrm{mM} \mathrm{NaCl}, 2.7 \mathrm{mM} \mathrm{KCl}, 4.3 \mathrm{mM} \mathrm{Na}_{2} \mathrm{HPO}_{4}$ and $1.4 \mathrm{mM} \mathrm{KH}_{2} \mathrm{PO}_{4}$ at a pH of 7.4, after a centrifugation at $1000 \times \mathrm{g}$ for $10 \mathrm{~min}$. Then, approximately $10^{7} \mathrm{CFU}$ of bacterial cells were incubated with $1.8 \mu \mathrm{g}$ of MLTphg dissolved in PBS to make a final volume of $1 \mathrm{~mL}$ and a final MLTphg concentration of $40 \mathrm{nM}$. For comparison between MLTphg and its parental lysins, the gradually increased concentrations of MLTphg or its parental lysins (from 0 to $40 \mathrm{nM}$ ) dissolved in PBS were incubated with the S. aureus cells at $37^{\circ} \mathrm{C}$ and $150 \mathrm{rpm}$ for 0 to $40 \mathrm{~min}$ (samples were taken and measured every $10 \mathrm{~min}$ ); then the viable cell numbers were counted and log kills were evaluated by plating the treated cells on LB agar plates and incubating at $37^{\circ} \mathrm{C}$ overnight. To evaluate the lytic spectrum of MLTphg and its parental lysins (see Table 1), a group of bacteria (approximately $10^{7} \mathrm{CFU} / \mathrm{mL}$ ) were incubated with MLTphg, MMPphg or TSPphg dissolved in PBS with a final concentration of $40 \mathrm{nM}$ in a final volume of $1 \mathrm{~mL}$. The mixtures were incubated at $37^{\circ} \mathrm{C}$ for $30 \mathrm{~min}$; then $50 \mu \mathrm{L}$ of 20 -fold serial dilution was spread onto LB agar plates; subsequently, the viable bacterial cell numbers were counted. Additionally, the $40 \mathrm{nM}$ of MLTphg, MMPphg and TSPphg is equivalent to the concentration of $1.8 \mu \mathrm{g} / \mathrm{mL}, 0.93 \mu \mathrm{g} / \mathrm{mL}$ and $0.73 \mu \mathrm{g} / \mathrm{mL}$ of these three lysins, respectively. All assays were repeated thrice. Finally, the bactericidal activity of purified MLTphg and its parental lysins was indicted as a bacterial cell number reduction in logarithmic units under the specific condition as 
follows: $\log _{10}\left(\mathrm{~N}_{0} / \mathrm{N}_{\mathrm{i}}\right), \mathrm{N}_{0}=$ number of untreated control cells and $\mathrm{N}_{\mathrm{i}}=$ number of cells treated by lysins, as described previously [14].

\subsection{Statistical Analysis}

All values were presented as mean \pm standard deviation (SD). Statistical significance was determined using $R$ version 3.2.2. $p$ value $<0.05$ was considered significant.

\section{Results}

\subsection{Construction of the Expression Vector for Chimeric Lysin MLTphg via Chimeolysin Bioengineering}

Previously, we have identified two thermostable lysins, MMPphg and TSPphg, derived from Meiothermus bacteriophage MMP7 and Thermus bacteriophage TSP4, respectively [14,24]. However, both MMPphg and TSPphg have a peak activity over a high temperature range of $50-65^{\circ} \mathrm{C}$. It has been reported that using the chimeolysin bioengineering to combine lysins of heterologous origins through some specifically designed protein domain linkers could remarkably contribute to the functional enhancement of effectiveness and practicability of chimeric proteins $[11,25,26]$. Thus, we joined MMPphg and TSPphg by a (GGGGS)3 flexible linker sequence, which has been highlighted to be able to separate two moieties at a favorable distance for conformational folding [12,27]. As further depicted in Figure 1, finally, the chimeric lysin MLTphg with a total length of $1173 \mathrm{bp}$ was constructed into the pET28a expression vector for recombinant protein overproduction.

\subsection{Overproduction and Purification of the Chimeric MLTphg Protein}

As depicted in Figure 2a, the DNA sequence of MLTphg was amplified by PCR, and the constructed recombinant vector (pET28a-MLTphg) containing the gene coding for MLTphg lysin was transformed into the host $E$. coli BL21(DE3) strain, which enabled overproduction of MLTphg harboring a N-terminal His-tag sequence. For recombinant expression of the chimeric MLTphg, the host E. coli BL21(DE3) cells carrying the vector were cultivated at $37^{\circ} \mathrm{C}$ in LB medium supplemented with Kanamycin $(50 \mu \mathrm{g} / \mathrm{mL}$ ), and lactose (with a final concentration of $1 \mathrm{~g} / \mathrm{L}$ ) was used for induction (Figure $2 \mathrm{~b}$ ). After lactose induction for $6 \mathrm{~h}$ at $37^{\circ} \mathrm{C}$, the bacterial cells were collected and the subsequent purification procedure using HisTrap affinity column (GE Healthcare, USA) was performed. Finally, the purity of recovered chimeric MLTphg lysin was confirmed by 12\% SDS-PAGE (Figure 2c), and we could obtain approximately $40 \pm 1.9 \mathrm{mg}$ of MLTphg lysin from $1 \mathrm{~L}$ of the host $E$. coli BL21(DE3) culture. As shown in Figure 2d, we further validated the capability of MLTphg to digest the bacterial cell wall obtained from Staphylococcus aureus ATCC6538, which is consistent with the original peptidoglycan-degrading activity of its parental lysins, MMPphg and TSPphg [14,24].

\subsection{Characterization of Purified MLTphg Activity}

$\mathrm{Next}$, the effects of $\mathrm{pH}$ and $\mathrm{NaCl}$ on the lytic activity of MLTphg were investigated. The bacterial cells used as the substrate for MLTphg lysin were Staphylococcus aureus ATCC6538. The pH range was examined from $\mathrm{pH} 4$ to $\mathrm{pH}$ 9, and the peak activity for MLTphg was observed at $\mathrm{pH} 8$ (Figure 3a). Furthermore, MLTphg exhibited the highest activity at $100 \mathrm{mM} \mathrm{NaCl}$ (Figure 3b), which makes it suitable for applications in similar physiological conditions [21,28]. As presented in Figure 3c, the optimal temperatures for MLTphg were studied in a range of 15 to $50^{\circ} \mathrm{C}$. We found that MLTphg showed more than $90 \%$ of its activity between 35 and $40^{\circ} \mathrm{C}$, and this is the favorite temperature range for a great number of bacteria. Interestingly, compared to its parental lysins MMPphg and TSPphg [14,24], MLTphg was considerably less thermostable, possibly caused by structural reorganization of the chimeric protein. Moreover, the effects of metal ions $\left(\mathrm{Na}^{+}, \mathrm{K}^{+}, \mathrm{Mg}^{2+}, \mathrm{Zn}^{2+}, \mathrm{Mn}^{2+}, \mathrm{Ca}^{2+}\right.$ and $\left.\mathrm{Fe}^{2+}\right)$ on the lytic activity of MLTphg were also measured. It can be seen from Figure $3 \mathrm{~d}$ that $\mathrm{Na}^{+}, \mathrm{K}^{+}$and $\mathrm{Mg}^{2+}$ displayed enhanced effects on MLTphg lytic activity. For example, MLTphg activity can be significantly reconstituted to be $160.5 \pm 0.7 \%$ compared with the untreated control $\left(p\right.$ value $=1.32 \times 10^{-8}$ 
by $\mathrm{Mg}^{2+}$ with a concentration of $1 \mathrm{mM}$. These results are in line with the function of MMPphg and TSPphg, the parental lysins of MLTphg both work as peptidoglycan hydrolases belonging to the M23 metallopeptidase family [14,24].

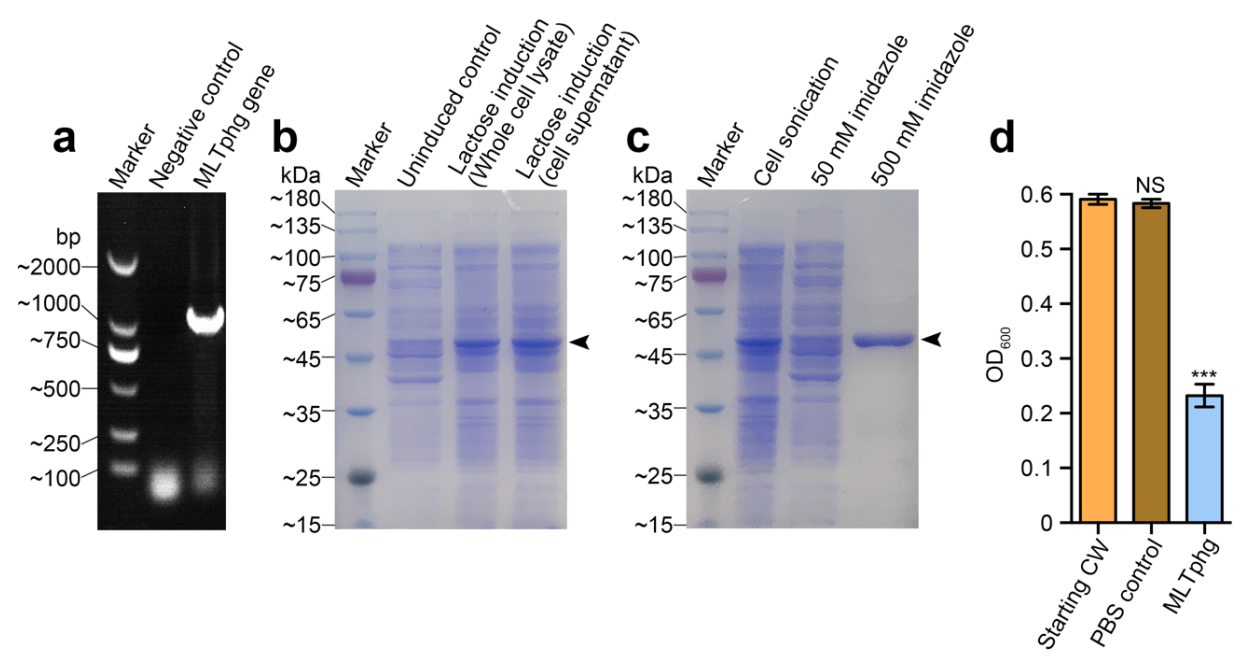

Figure 2. Gene cloning, protein overproduction and purification of MLTphg, and functional validation of cell wall hydrolytic activity of MLTphg. (a) PCR amplification of MLTphg gene. (b) Lactose (1 g/L) was used for induction to overproduce MLTphg. (c) SDS-PAGE analysis of purification of the recombinant MLTphg, which is at approximately $46 \mathrm{kDa}$ as the black arrowhead indicates. (d) MLTphg can digest cell wall (CW) extracted from Staphylococcus aureus ATCC6538. Error bars denote the standard deviation. $p$ Values were calculated using the Student's $t$ test. ${ }^{* * *}, p<0.001$; NS, not significant.

a

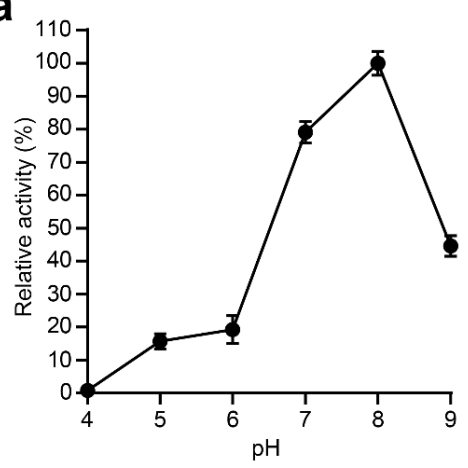

C

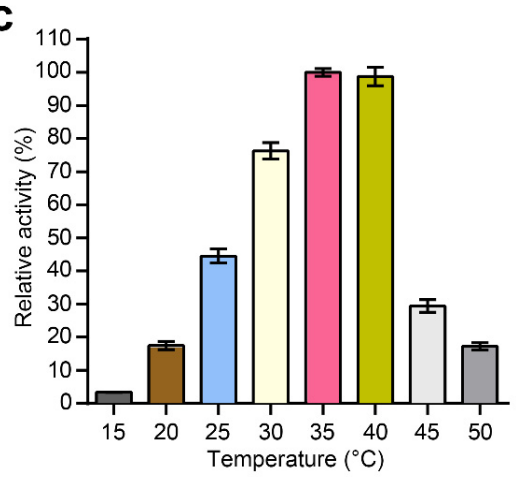

b

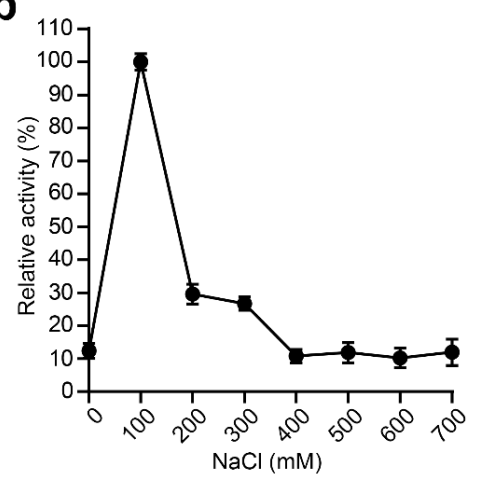

d

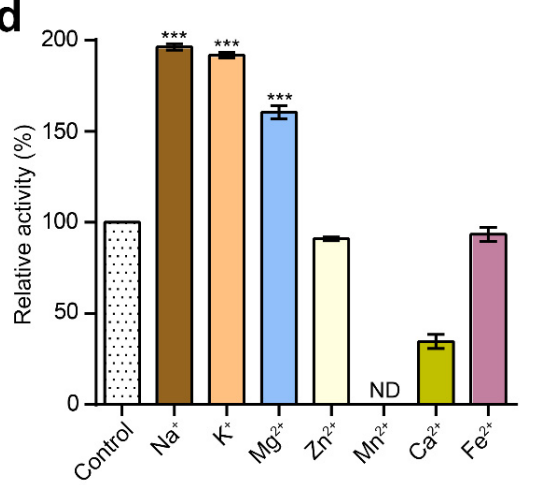

Figure 3. Characterization of the purified MLTphg activity. Effects of $\mathrm{pH}$ values (a), $\mathrm{NaCl}$ concentrations (b) and temperatures (c) on the lytic activity of MLTphg, which were measured by the standard turbidity reduction assays. (d) The effects of different metal ions on the lytic activity of MLTphg. Error bars denote the standard deviation $(\mathrm{n}=3) . p$ Values were calculated using the Student's $t$ test. ${ }^{* * *}, p<0.001$; ND, non-detectable. 


\subsection{Chimeric MLTphg Kills Staphylococcus aureus More Effectively than Its Parental Lysins}

To further study the enhancement of antimicrobial activity of MLTphg compared with its parental lysins MMPphg and TSPphg, the bactericidal activity of MLTphg and its parental lysins was carried out against Staphylococcus aureus ATCC 6538 at $37^{\circ} \mathrm{C}$ in dose-dependent and time-kill curve experiments. For the dose-dependent assay, the same incubation time of MLTphg and its two parental lysins with the bacteria for $30 \mathrm{~min}$ was set, and gradually increasing concentrations $(0-40 \mathrm{nM})$ of these lysins (or equivalently mixed free MMPphg + free TSPphg) were used (Figure 4a). We found that the bactericidal activity of these groups increased in correlation with their concentrations. Especially, the curve pattern of MLTphg displayed more rapid kinetics of bacterial cell lysis than those of its parental lysins MMPphg and TSPphg. It is noteworthy that with the concentration of $40 \mathrm{nM}, \mathrm{a} \log _{10}$ reduction by $2.9 \pm 0.1$ in bacterial cell counts was observed upon incubation of $10^{7} \mathrm{CFU} / \mathrm{mL}$ of Staphylococcus aureus cultures with MLTphg for $30 \mathrm{~min}$ at $37^{\circ} \mathrm{C}$ (Figure 4a), which is significantly better than TSPphg, MMPphg and MMPphg + TSPphg groups ( $p$ value $=9.32 \times 10^{-6}$ for MLTphg versus PBS-treated control, $1.62 \times 10^{-4}$ for MLTphg versus TSPphg, $7.65 \times 10^{-4}$ for MLTphg versus MMPphg, and $2.36 \times 10^{-4}$ for MLTphg versus MMPphg + TSPphg, respectively). For the time-kill curve experiment, the same concentration of $40 \mathrm{nM}$ of these lysins (or $20 \mathrm{nM}$ MMPphg $+20 \mathrm{nM}$ TSPphg) was used, and their log kills at different time points (from 0 to $40 \mathrm{~min}$ with an interval of $10 \mathrm{~min}$ ) were compared (Figure $4 \mathrm{~b}$ ). Remarkably, MLTphg functions more quickly than its parental lysins, MMPphg and TSPphg. With the same concentration of $40 \mathrm{nM}$, incubation of MLTphg, TSPphg, MMPphg and $20 \mathrm{nM}$ MMPphg + $20 \mathrm{nM}$ TSPphg with the bacterial cell suspensions for $40 \mathrm{~min}$ was capable of leading to the $\log _{10}$ reduction in bacterial cell counts by $3.0 \pm 0.2,1.4 \pm 0.2,1.8 \pm 0.2$ and $1.6 \pm 0.1$ respectively $\left(p\right.$ value $=5.98 \times 10^{-5}$ for MLTphg versus PBS-treated control, $1.13 \times 10^{-3}$ for MLTphg versus TSPphg, $2.22 \times 10^{-3}$ for MLTphg versus MMPphg and $5.25 \times 10^{-4}$ for MLTphg versus $20 \mathrm{nM}$ MMPphg + $20 \mathrm{nM}$ TSPphg, respectively). In addition, it appears that there was no remarkable synergy between free MMPphg and free TSPphg. Instead, the upgraded activity of MLTphg resulted from the fusion of MMPphg and TSPphg via the (GGGGS)3 flexible linker (Figure 4a,b).

\subsection{Comparison of Bactericidal Activity between MLTphg and Its Parental Lysins against Various Gram-Negative or Gram-Positive Bacteria}

Furthermore, the antibacterial activity of MLTphg, TSPphg and MMPphg against various Gram-negative or Gram-positive bacteria were compared. As presented in Table 1, it can be seen that these lysins exhibited antimicrobial activity against various Gram-negative or Gram-positive strains. In the cases of Gram-negative strains of Salmonella ser. Paratyphi B, Salmonella ser. Enteritidis, Salmonella ser. Typhi and Klebsiella pneumoniae and Gram-positive strain of Staphylococcus aureus, the considerable enhancement by at least one log killing for MLTphg lysin activity was observed in comparison to its parental lysins TSPphg, MMPphg or equivalently mixed MMPphg + TSPphg. Together, these findings indicate the potential applications of chimeric MLTphg lysin in the field of microbial biotechnology. 

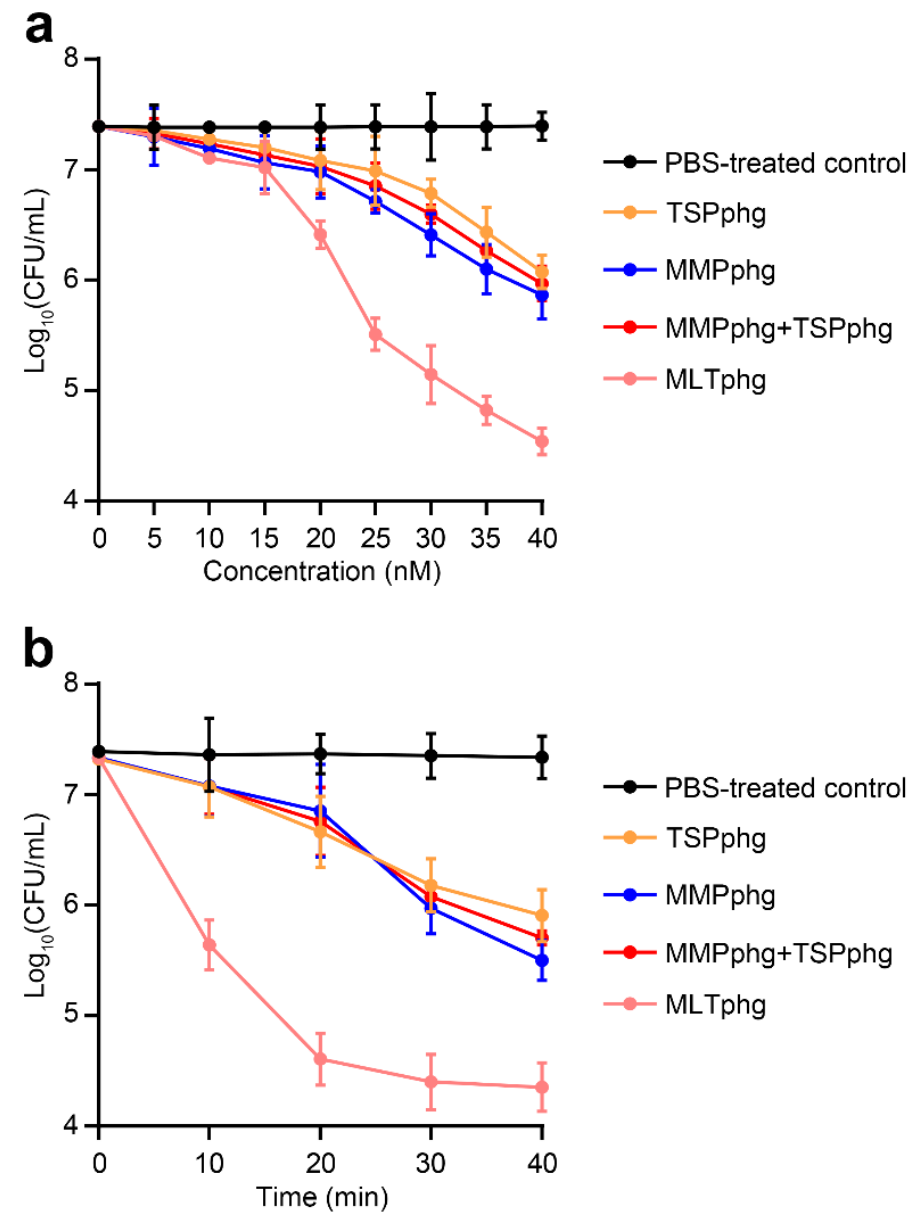

Figure 4. Comparison of the bactericidal activity between MLTphg and its parental lysins against Staphylococcus aureus ATCC6538 in dose-dependent and time-kill curve experiments. (a) With the same incubation time of $30 \mathrm{~min}$, dependence of antimicrobial activity of MLTphg and its parental lysins on their concentrations was examined. For free MMPphg plus a free TSPphg group, the two lysins were always equivalently mixed at different concentrations. (b) The time-kill curve assay. With the same concentration of $40 \mathrm{nM}$ of these three lysins (or $20 \mathrm{nM}$ MMPphg + $20 \mathrm{nM}$ TSPphg), the log kills in bacteria cell counts were recorded over incubation time (with an interval of $10 \mathrm{~min}$ ), and aliquots were serially diluted and spread onto LB agar plates. PBS was designed as the control. Values were indicted as mean $\pm \operatorname{SD}(\mathrm{n}=3)$.

\section{Discussion}

Previously, we reported that both parental lysins of MLTphg, TSPphg and MMPphg, contain a conserved M23 peptidase domain (NCBI domain ID: 10480195) and belong to a peptidase of M23 family (accession: pfam01551) [14,24]. In this study, we further showed that the combination of these two domains through bioengineering is associated with highly increased antibacterial activity, which is in line with a number of recent studies highlighting that modification or engineering approaches such as fusion to polycationic and hydrophobic/amphipathic peptides, domain shuffling, site-directed mutagenesis and a combination of endolysin functional domains of heterologous origins are capable of producing chimeolysins with improved properties [5,6,29,30]. For example, Csl2, a chimeric lytic enzyme resulting from combining the catalytic domain (EAD) of Cpl-7 endolysin of pneumococcal phage Cp-7 with the cell binding domain (CBD) of LySMP endolysin of Streptococcus suis phage SMP, exhibited better antibacterial and antibiofilm activity than its parental LysSMP [8]. Considering the mutual beneficial features between $\mathrm{EAD}$ and $\mathrm{CBD}$, most current studies mainly center on the fusion of at least one EAD and one CBD together, creating a combinatorial chimeolysin. Generally, these two domains work in concert and the produced chimeric enzymes show increased antimicrobial activity and/or 
greater expansion of the lytic spectrum [3]. Interestingly, Becker et al. have observed that the resistance development for a triple-EAD fusion (containing two EADs of LysK and one EAD of lysostaphin) was remarkably reduced compared with the parental LysK and lysostaphin [31]. More surprisingly, Low et al. reported that some EADs themselves also have the intrinsic binding capacity to a cell wall [32]. These results suggest the multifunctionality and complexity of endolysin EADs. Generally speaking, the reasons for the abovementioned enhancements are still not fully revealed, probably because the intrinsic features of these functional domains are still maintained after being tailored, and it is conceivable that the peptidoglycan bonds are more easily damaged owing to the synergistic effect between the fusion domains [3]. In the case of chimeric MLTphg protein, future structural investigations will be required to uncover detailed mechanism and to further optimize its effectiveness.

In the starting experiments of this study, we just simply combined two parental lysins of MLTphg together with no insertion of any domain linker, and it turned out that the recombinant fusion protein was insoluble and mainly existed in the inclusion body. Subsequently, we inserted the flexible (GGGGS)3 linker sequence between MMPphg and TSPphg, and successfully obtained bioactive and soluble chimeric MLTphg protein (Figures 1 and 2), which is consistent with previous reports that have highlighted the importance of domain linkers such as the flexible peptides (GGGGS)n (usually $\mathrm{n} \leq 6$ ) and the monomeric $\alpha$-helical (EAAAK)n (usually $\mathrm{n} \leq 3$ ) in working as a scaffold for beneficial conformational folding between two moieties [12,27]. Lu et al. have further uncovered that the linker length and their amino acid composition were closely associated with their overall performance [11], and it would be necessary to optimize the linker sequences in creating a desirable chimeric protein.

Given the existence of an impermeable outer membrane (OM) in Gram-negative bacteria, phage lysins targeting cell walls of these pathogens have once been a no-go [33]. Nowadays, the discovery of many intrinsic antibacterial lysins being capable of passing the OM have made it no longer an unrealistic task, and most of these lysins have special features of C-terminal amphipathic helix or the $\mathrm{N}$-terminal cationic tail [33]. Especially, the novel strategies to design chimeric lysins by configuring them with the ability to penetrate the OM have been widely developed based on protein engineering or the Artilysin technology [3,29]. Very recently, Gerstmans et al. constructed a large library of engineered lysins carrying a combination of four modules (OMP-linker-CBD-EAD), and they could create an unlimited number of chimeric lysins using an iterative three-step approach. Finally, with this high-throughput VersaTile-driven platform, fighting against an outrageous diversity of bacterial pathogens is conceivable [34]. Together, these endolysin-based strategies provide the fundamental basis for combating antibiotic-resistant bacteria.

Apart from phage endolysins, identifying efflux pump inhibitory molecules, e.g., P-glycoproteins, would be another approach to combat the continuous rise of MDR pathogens [35]. In addition, an array of recent studies has also demonstrated that some natural products such as DCMF from M. caesalpiniifolia and P. amarus ethanoic extracts could function as pump inhibitors and interact with conventional antibiotics fighting against pathogenic resistance [36,37]. These natural or synthetic pumps inhibitors can also be covalently joined together as a hybrid, which indeed showed surprisingly in vitro and in vivo antimicrobial activity [38].

In conclusion, through a bioengineering strategy, here we generated the chimeric MLTphg lysin by joining MMPphg endolysin originating from Meiothermus bacteriophage MMP7 and TSPphg endolysin from Thermus bacteriophage TSP4 via an oligopeptide glycine/serine linker (GGGGS)3, which physically separates functional domains of the fusion protein, rendering MLTphg strong solubility and upgraded bactericidal activity against Staphylococcus aureus and also a group of Gram-negative or Gram-positive pathogens compared with its parental lysins. Nevertheless, these findings are just in vitro data. In the future, more clinically related MIC (minimum inhibitory concentration) assays, in vivo measurements and any possible increase in cytotoxicity of the chimeric MLTphg lysin are still needed to explore to further reveal the clinical significance of MLTphg. However, considering the well-presented concerns 
related to mounting bacterial resistance, our results shed light on bioengineering strategies to develop bacteriophage-derived antimicrobials as alternatives to conventional antibiotics.

Author Contributions: Conceptualization, L.L. and F.W.; Data curation, X.L. and F.W.; Formal analysis, F.W. and X.L.; Funding acquisition, L.L. and F.W.; Investigation, X.L., Z.D., Y.Z., X.J. and Y.X.; Methodology, Z.D., X.J. and Y.X.; Project administration, F.W.; Software, F.W.; Supervision, F.W. and L.L.; Validation, Y.Z.; Visualization, F.W.; Writing-original draft, F.W.; Writing-review and editing, F.W. and L.L. All authors have read and agreed to the published version of the manuscript.

Funding: This study was supported by the Natural Science Foundation of China under Grant No. 31760042 to L.B.L. and Yunnan Fundamental Research Projects (grant No. 202001AT070048, the year of 2020) to F.W.

Conflicts of Interest: The authors declare no conflict of interest. The funders had no role in the design of the study; in the collection, analyses, or interpretation of data; in the writing of the manuscript, or in the decision to publish the results.

\section{References}

1. Fischetti, V.A. Development of phage lysins as novel therapeutics: A historical perspective. Viruses 2018, 10, 310. [CrossRef] [PubMed]

2. Nakonieczna, A.; Cooper, C.J.; Gryko, R. Bacteriophages and bacteriophage-derived endolysins as potential therapeutics to combat Gram-positive spore forming bacteria. J. Appl. Microbiol. 2015, 119, 620-631. [CrossRef] [PubMed]

3. Sao-Jose, C. Engineering of phage-derived lytic enzymes: Improving their potential as antimicrobials. Antibiotics 2018, 7, 29. [CrossRef] [PubMed]

4. Yang, H.; Yu, J.; Wei, H. Engineered bacteriophage lysins as novel anti-infectives. Front. Microbiol. 2014, 5, 542. [CrossRef]

5. Gerstmans, H.; Criel, B.; Briers, Y. Synthetic biology of modular endolysins. Biotechnol. Adv. 2018, 36, 624-640. [CrossRef]

6. Roach, D.R.; Donovan, D.M. Antimicrobial bacteriophage-derived proteins and therapeutic applications. Bacteriophage 2015, 5, 1062590. [CrossRef]

7. Blázquez, B.; Fresco-Taboada, A.; Iglesias-Bexiga, M.; Menéndez, M.; García, P. Pl3 amidase, a tailor-made lysin constructed by domain shuffling with potent killing activity against Pneumococci and related species. Front. Microbiol. 2016, 7, 1156. [CrossRef]

8. Vázquez, R.; Domenech, M.; Iglesias-Bexiga, M.; Menéndez, M.; García, P. Csl2, a novel chimeric bacteriophage lysin to fight infections caused by Streptococcus suis, an emerging zoonotic pathogen. Sci. Rep. 2017, 7, 16506. [CrossRef]

9. Díez-Martínez, R.; De Paz, H.D.; García-Fernández, E.; Bustamante, N.; Euler, C.W.; Fischetti, V.A.; Menendez, M.; García, P. A novel chimeric phage lysin with high in vitro and in vivo bactericidal activity against Streptococcus pneumoniae. J. Antimicrob. Chemother. 2015, 70, 1763-1773. [CrossRef]

10. Crasto, C.J.; Feng, J.A. Linker: A program to generate linker sequences for fusion proteins. Protein Eng. 2000, 13, 309-312. [CrossRef]

11. Lu, P.; Feng, M.G. Bifunctional enhancement of a beta-glucanase-xylanase fusion enzyme by optimization of peptide linkers. Appl. Microbiol. Biotechnol. 2008, 79, 579-587. [CrossRef]

12. Trinh, R.; Gurbaxani, B.; Morrison, S.L.; Seyfzadeh, M. Optimization of codon pair use within the (GGGGS)3 linker sequence results in enhanced protein expression. Mol. Immunol. 2004, 40, 717-722. [CrossRef]

13. Wang, F.; Xiao, Y.; Xiong, Y.; Jiao, Y.; Zhang, Q.; Lin, L. Complete genome sequence of MMP7, a novel Meiothermus bacteriophage of the family Myoviridae isolated from a hot spring. Arch. Virol. 2020, 165, 753-756. [CrossRef]

14. Wang, F.; Ji, X.; Li, Q.; Zhang, G.; Peng, J.; Hai, J.; Zhang, Y.; Ci, B.; Li, H.; Xiong, Y.; et al. TSPphg lysin from the extremophilic Thermus bacteriophage TSP4 as a potential antimicrobial agent against both gram-negative and gram-positive pathogenic bacteria. Viruses 2020, 12, 192. [CrossRef] [PubMed]

15. Lin, L.; Hong, W.; Ji, X.; Han, J.; Huang, L.; Wei, Y. Isolation and characterization of an extremely long tail Thermus bacteriophage from tengchong hot springs in China. J. Basic. Microbiol. 2010, 50, 452-456. [CrossRef] [PubMed] 
16. Lin, L.; Han, J.; Ji, X.; Hong, W.; Huang, L.; Wei, Y. Isolation and characterization of a new bacteriophage MMP17 from Meiothermus. Extremophiles 2011, 15, 253-258. [CrossRef]

17. Girija, A.S.; Priyadharsini, J.V. CLSI based antibiogram profile and the detection of MDR and XDR strains of Acinetobacter baumannii isolated from urine samples. Med. J. Islam Repub. Iran 2019, 33, 3. [CrossRef]

18. Crump, J.A.; Sjölund-Karlsson, M.; Gordon, M.A.; Parry, C.M. Epidemiology, clinical presentation, laboratory diagnosis, antimicrobial resistance, and antimicrobial management of invasive Salmonella infections. Clin. Microbiol. Rev. 2015, 28, 901-937. [CrossRef] [PubMed]

19. Wang, F.; Ji, X.; Chen, M.; Guo, J.; Deng, X.; Lin, L. Rapid purification of bacteriophage endolysin TSPphg and its exogenous treatment could act as an alternative bacterial cell disruption method. Protein Expr. Purif. 2018, 148, 54-58. [CrossRef] [PubMed]

20. Wang, G.; Li, Z.; Li, T.; Wang, S.; Zhang, L. Negative-pressure wound therapy in a Pseudomonas aeruginosa infection model. Biomed. Res. Int. 2018, 2018, 9496183. [CrossRef] [PubMed]

21. Plotka, M.; Kaczorowska, A.K.; Morzywolek, A.; Makowska, J.; Kozlowski, L.P.; Thorisdottir, A.; Skirnisdottir, S.; Hjorleifsdottir, S.; Fridjonsson, O.H.; Hreggvidsson, G.O.; et al. Biochemical characterization and validation of a catalytic site of a highly thermostable Ts2631 endolysin from the Thermus scotoductus phage vB_Tsc2631. PLoS ONE 2015, 10, 0137374. [CrossRef] [PubMed]

22. Plotka, M.; Kapusta, M.; Dorawa, S.; Kaczorowska, A.K.; Kaczorowski, T. Ts2631 endolysin from the extremophilic Thermus scotoductus bacteriophage vB_Tsc2631 as an antimicrobial agent against Gram-negative multidrug-resistant bacteria. Viruses 2019, 11, 657. [CrossRef] [PubMed]

23. Yang, H.; Wang, M.; Yu, J.; Wei, H. Antibacterial activity of a novel peptide-modified lysin against Acinetobacter baumannii and Pseudomonas aeruginosa. Front. Microbiol. 2015, 6, 1471. [CrossRef] [PubMed]

24. Wang, F.; Xiong, Y.; Xiao, Y.; Han, J.; Deng, X.; Lin, L. MMPphg from the thermophilic Meiothermus bacteriophage MMP17 as a potential antimicrobial agent against both gram-negative and gram-positive bacteria. Virol. J. 2020, 17, 130. [CrossRef]

25. George, R.A.; Heringa, J. An analysis of protein domain linkers: Their classification and role in protein folding. Protein Eng. 2002, 15, 871-879. [CrossRef]

26. Arai, R.; Wriggers, W.; Nishikawa, Y.; Nagamune, T.; Fujisawa, T. Conformations of variably linked chimeric proteins evaluated by synchrotron X-ray small-angle scattering. Proteins 2004, 57, 829-838. [CrossRef]

27. Kabiri, M.; Tafaghodi, M.; Saberi, M.R.; Moghadam, M.; Rezaee, S.A.; Sankian, M. Separation of the epitopes in a multi-epitope chimera: Helical or flexible linkers. Protein Pept. Lett. 2020, 27, 604-613. [CrossRef]

28. Yoong, P.; Schuch, R.; Nelson, D.; Fischetti, V.A. Identification of a broadly active phage lytic enzyme with lethal activity against antibiotic-resistant Enterococcus faecalis and Enterococcus faecium. J. Bacteriol. 2004, 186, 4808-4812. [CrossRef]

29. Briers, Y.; Walmagh, M.; Van Puyenbroeck, V.; Cornelissen, A.; Cenens, W.; Aertsen, A.; Oliveira, H.; Azeredo, J.; Verween, G.; Pirnay, J.P.; et al. Engineered endolysin-based "Artilysins" to combat multidrug-resistant Gram-negative pathogens. mBio 2014, 5, e01379-14. [CrossRef]

30. Briers, Y.; Lavigne, R. Breaking barriers: Expansion of the use of endolysins as novel antibacterials against Gram-negative bacteria. Future Microbiol. 2015, 10, 377-390. [CrossRef]

31. Becker, S.C.; Roach, D.R.; Chauhan, V.S.; Shen, Y.; Foster-Frey, J.; Powell, A.M.; Bauchan, G.; Lease, R.A.; Mohammadi, H.; Harty, W.J.; et al. Triple-acting lytic enzyme treatment of drug-resistant and intracellular Staphylococcus aureus. Sci. Rep. 2016, 6, 25063. [CrossRef]

32. Low, L.Y.; Yang, C.; Perego, M.; Osterman, A.; Liddington, R. Role of net charge on catalytic domain and influence of cell wall binding domain on bactericidal activity, specificity, and host range of phage lysins. J. Biol. Chem. 2011, 286, 34391-34403. [CrossRef] [PubMed]

33. Gutiérrez, D.; Briers, Y. Lysins breaking down the walls of gram-negative bacteria, no longer a no-go. Curr. Opin. Biotechnol. 2020, 68, 15-22. [CrossRef] [PubMed]

34. Gerstmans, H.; Grimon, D.; Gutiérrez, D.; Lood, C.; Rodríguez, A.; Van Noort, V.; Lammertyn, J.; Lavigne, R.; Briers, Y. A VersaTile-driven platform for rapid hit-to-lead development of engineered lysins. Sci. Adv. 2020, 6, eaaz1136. [CrossRef] [PubMed]

35. Usai, D.; Donadu, M.; Bua, A.; Molicotti, P.; Zanetti, S.; Piras, S.; Corona, P.; Ibba, R.; Carta, A. Enhancement of antimicrobial activity of pump inhibitors associating drugs. J. Infect. Dev. Ctries. 2019, 13, 162-164. [CrossRef] [PubMed] 
36. Silva, S.W.C.; Monção, N.B.N.; Araújo, B.Q.; Arcanjo, D.D.R.; Ferreira, J.H.L.; Lima Neto, J.S.; Citó, A.M.D.G.L.; De Siqueira Júnior, J.P.; Kaatz, G.W.; Barreto, H.M.; et al. Antimicrobial activity of Mimosa caesalpiniifolia Benth and its interaction with antibiotics against Staphylococcus aureus strains overexpressing efflux pump genes. Lett. Appl. Microbiol. 2019, 69, 57-63. [CrossRef] [PubMed]

37. Ribeiro, A.M.B.; Sousa, J.N.; Costa, L.M.; Oliveira, F.A.A.; Dos Santos, R.C.; Nunes, A.S.S.; Da Silva, W.O.; Cordeiro, P.J.M.; De Sousa, J.L.N.; De Siqueira-Júnior, J.P.; et al. Antimicrobial activity of Phyllanthus amarus Schumach. \& Thonn and inhibition of the NorA efflux pump of Staphylococcus aureus by Phyllanthin. Microb. Pathog. 2019, 130, 242-246. [CrossRef]

38. Rineh, A.; Bremner, J.B.; Hamblin, M.R.; Ball, A.R.; Tegos, G.P.; Kelso, M.J. Attaching NorA efflux pump inhibitors to methylene blue enhances antimicrobial photodynamic inactivation of Escherichia coli and Acinetobacter baumannii in vitro and in vivo. Bioorg. Med. Chem. Lett. 2018, 28, 2736-2740. [CrossRef]

Publisher's Note: MDPI stays neutral with regard to jurisdictional claims in published maps and institutional affiliations.

(C) 2020 by the authors. Licensee MDPI, Basel, Switzerland. This article is an open access article distributed under the terms and conditions of the Creative Commons Attribution (CC BY) license (http://creativecommons.org/licenses/by/4.0/). 